\title{
ANALYSIS OF EFFECT OF FIRM SIZE, INSTITUTIONAL OWNERSHIP, PROFITABILITY, AND LEVERAGE ON FIRM VALUE WITH CORPORATE SOCIAL RESPONSIBILITY (CSR) DISCLOSURE AS INTERVENING VARIABLES (Study on Banking Companies Listed on BEI Period 2012-2016)
}

\author{
Fitria Yuni Astuti ${ }^{1}$, Sugeng Wahyudi ${ }^{2}$, Wisnu Mawardi ${ }^{3}$ \\ ${ }^{1}$ Master of Management, Faculty of Economics and Business, Diponegoro University \\ ${ }^{2}$ Master of Management, Faculty of Economics and Business, Diponegoro University \\ ${ }_{3}^{3}$ Master of Management, Faculty of Economics and Business, Diponegoro University
}

\begin{abstract}
The main objective of the company survives in the stringent competitive by maximizing the value of the company to shareholder wealth. Firm value is experiencing a downward trend is a problem that must be resolved. The banking company also undertakes a social responsibility that is perceived to have a positive impact on the company's image. This study aimed to analyze the effect of the firm size, institutional ownership, profitability, and leverage with corporate social responsibility (CSR) disclosure as a variable intervening.

Populations are banking companies listed on the Indonesia Stock Exchange Period 20122016. Sampling technique used is purposive sampling with 29 companies selected according to predetermined criteria. This research is done by using multiple linear regression analysis methods and path analysis also Sobel test to examine the effect of intervening.

Test results with CSRD as the dependent variable indicate that institutional ownership and Leverage have no effect on CSRD While firm size and profitability (ROA) have a positive significant effect on CSRD. The result of testing with Firm Value (Tobins'Q) as the dependent variable indicates that Firm Size, Institutional Ownership, and Profitability (ROA) have no effect on Firm Value (Tobins' $Q$ ). Leverage (DAR) has a negative and significant influence on Firm Value (Tobins' $Q$ ) while CSRD has a significant positive effect on Firm Value (Tobins'Q). CSRD does not mediate the effect of Institutional Ownership, Profitability (ROA) and Leverage (DAR) on Firm Value (Tobins'Q). CSRD mediates the effect of Firm Size on Firm Value (Tobins'Q).
\end{abstract}

Keywords: Firm Size, Institutional Ownership, Profitability, Leverage, CSR Disclosure, Firm Value.

\section{INTRODUCTION}

As the growth of the company is surely faced by a tight competition to survive, so the company will be vying to increase economic growth, as well as achieve optimal profit according to the planned targets, continuing the company's sustainability and dominate the market. 
Firm value is very important to the company. The value of the company is the investor's view of the good and bad of the company's performance. Obviously with high company value makes investors believe in prospects in the future which is generally seen on the increase in stock prices that will provide welfare to shareholders (Wahyudi, 2013)

An economic decision taken by investors and corporate management is not only about financial performance alone, but social information is also a consideration for investors and management. As cited by Anggraini (2006), Eipstein and Freedman (1994) annual financial reports reported on social information are an attraction for individual investors. So the importance of disclosure of social information into consideration for a company, especially companies that go public.

\section{LITERATURE REVIEW Agency Theory}

Agency Theory describes the correlation between the shareholder and the management. According to Jensen \&Meckling (1976), Management is defined as contracted and entrusted to perform the task on behalf of the principal as a mandate run by the management (agent). According to Masdupi (2005) agency problem potentially if the ownership of managerial (insider ownership) less than one hundred percent According to agency theory problem between management and shareholder can be reduced by equalizing management interest with hope of decision which has taken managers can be felt directly benefit and conflict of interest happened because of excess cash flow. The shareholder requires high-risk investments and high returns, while management chooses investments at low risk.

\section{Legitimacy Theory}

The underlying Legitimacy Theory is the relationship between the company and society in a social contract where the company operates using economic resources. In this theory not only focus on the interests of investors but also focus on the public interest. The Company seeks to gain legitimacy from social and environmental activities through disclosure in the reporting published in the company's annual report.

O'Donovan (2002) in Nor Hadi (2011: 87) states that the legitimacy of the organization is something that society gives to the company and what the company seeks out of society. It can be said that the legitimacy emphasizes the company in conducting social and environmental activities as a potential source for the company to survive so it needs to pay attention to social norms and values to be accepted by the environment.

\section{Pecking Order Theory}

According to Myers 1984, this theory originally from Donaldson (1961) is about the sequence of funding made by the company. The first of the companies internal is of retained earnings, the second if insufficient, the company chooses external funding sources ie from debt and the last option of equity. In general, companies prefer debt options because the cost is cheaper than the cost of equity issuance.

\section{Signaling Theory}

Bringham\& Houston (2006) explain that this theory becomes an investor's view of the prospects of the company. The signal is important because it will impact investment decisions from potential investors. These gestures can be in the past, present or future, as they relate to the continuity of the company, what may happen to a company. Information relating 
to the company becomes very important because it impacts investment decisions from outside the company.

\section{Company Value}

According to Solvatore (2005), the aim of the company is to maximize the wealth or value of the company. In this study will discuss the value of the company on the stock price approach by using Tobins'Q proposed by Professor James Tobin (1967). The Tobins' $Q$ ratio shows an estimate of the return value in the financial markets of each incremental investment dollar. According to Weston \&Copelan (2008: $244)$, the measurement of company value by using Tobins' $Q$ ratio is to compare the market value of a company listed in the financial market with the value of the replacement of company assets.

\section{Definition of Bank}

According to Act Number 7 of 1992 on Banking.The bank is a business entity that collects funds from the public in the form of deposits and channeled to the community in order to improve the standard of living of many people.

\section{Corporate social responsibility}

During operational activities, the company has a social obligation in relation to the surrounding environment which is now better known as CSR. The first originator is Howard R. Bowen (1953) in a book that has the meaning of a corporate obligation and the values of a society (Social Responsibilities of the Businessman). In Indonesia, CSR activities have been contained in Law No. 40 of 2007 on Limited Liability Company. Within the Law Number 25 of 2007 Article 15 letter b states, "Every investor is obliged: (b) carrying out corporate social responsibility." So with reference to this provision, the company in natural resources or not, shall perform CSR. For CSR companies appear not just profitability but more on the sustainability of the long-term company.

\section{Corporate Social Responsibility Disclosure (CSRD)}

Disclosure of social responsibility better known as CSRD is also called social disclosure, corporate social reporting, social accounting (Mathews, 1995) or corporate social responsibility (Hackston and Milne, 1996) is the process of communicating the social and environmental impacts of the organization's economic activities on groups special interest and to the community as a whole. Disclosure of CSR in this study refers to Sembiring (2005) banking company, consisting of 63 items CSR disclosure.

\section{Previous Researches}

The research conducted by Farida Ihwandarti (2010) on the Influence of Corporate Characteristics on Company value and Social Information Disclosure as Intervening Variable uses multiple regression analysis methods which shows that Profitability has no significant effect to Social Information Disclosure, Social Information Disclosure has no effect on Company value. Profitability has no effect on Company value.

BramantyoAdhiCahya (2011) Analysis of the Effect of Financial Performance on Corporate Social Responsibility (CSR) Study at Bank In Indonesia Period 2007-2008 using multiple regression analysis methods indicating that company size and leverage have a positive effect to CSRD. ROA has no significant effect on CSRD.

Yao, Shujie et al (2015) Determinants Of Social Responsibility Disclosure By Chinese Firms. using multiple regression analysis methods indicating that Company Size and Institutional Ownership have a positive effect on CSRD. 
Olivia Tjia and Lulu Setiawati (2012) Effect of CSR Disclosure to Value of the Firm: Study for Banking Industry in Indonesia using simple regression analysis method shows that CSRD has no significant effect on firm value. Sitorus, Tigor (2013) Corporate Social Responsibility as Company values: Empirical Study at Indonesian Stock Exchange 2012 using multiple regression analysis and analysis path method shows that CSRD has significant effect on company value. Habbash Murya (2016) Corporate Governance and Corporate Social Responsibility Disclosure: Evidence From Saudi Arabia using multiple regression analysis indicates that positive Institutional Ownership has no effect on CSRD, Firm Size positively affects CSRD, ROA has no effect on CSRD.

Figure 1

Research Framework

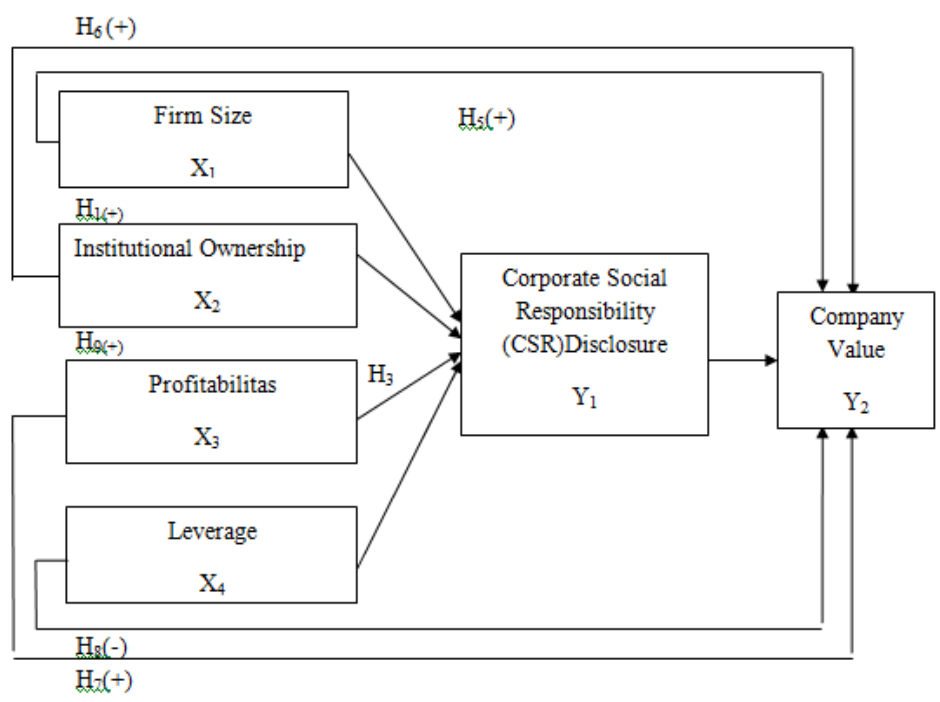

\section{METHOD}

\section{Sources of Data}

In this study data sources obtained from secondary data, among others, from ICMD data and annual reports, banking companies in the BEI period 2012-2016.

\section{Population and Sample}

The population is banking companies listed on the BEI in 2012-2016, wherein determining the sample using purposive sampling method, that is using certain considerations in choosing a sample not randomly (Indriatmo and Supomo, 2002: 131). The final samples of the data are 29 companies, for five years of research.

\section{Operational Definition of Variables Dependent variable $\left(\mathrm{Y}_{2}\right)$}

The dependent variable is an influenced variable or a variable which becomes the result of the existence of an independent variable (Sugiyono, 2009: 39). The dependent variable in this study is a firm value measured using Tobin's $Q$. The value of Tobin's $Q$ is the sum of the market value of the stock and the market value of the debt compared to the value of all capital placed in the asset. (Sudiyatno and Puspitasari, 2010). Here's the formula for company value:

Tobin's $Q=\frac{\text { EMV+DEBT }}{T A}$ 
EMV (Equity Market Value) $=$ closing stock price $\mathrm{x}$ number of shares outstanding, EMV means the valuation of the market equity value of firm according to market players (investors). DEBT = total debt at the end of the year, $\mathrm{TA}=$ total assets.

Intervening variable $\left(\mathrm{Y}_{1}\right)$

An intervening variable is a variable that affect the relationship indirectly between independent variables onthe dependent variable (Ghozali, 2013). Intervention variable in this research is Corporate Social Responsibility Disclosure (CSRD). According to Darwin (2004) in Anggraini (2006), Corporate Social Responsibility (CSR) is a mechanism for an organization to voluntarily integrate environmental and social concerns into its operations and its interactions with interested parties. The CSR Disclosure Formula as follows:

$\operatorname{CSRDIj}=\frac{\sum \mathrm{Xij}}{\mathrm{nj}}$

Explanation: $\mathrm{CSRDIj}=$ Corporate Social Responsibility Disclosure Company Index j; $\mathrm{Xij}=$ dummy variable $1=$ if there is disclosure; 0 = if item $\mathrm{i}$ is not disclosed; $\mathrm{nj=}$ there are 63 items of banking company disclosure (Sembiring, 2005).

\section{Independent variable}

The independent variable is the variable that becomes the cause of the dependent variable (Sugiyono, 2009: 59). The independent variables in this research are:

Firm Size

Firm size is large scale or small company (Sudarmadji\&Sularto, 2007). According to Klapper \& Love (2002) in Darmawati (2005) company size is proxied using natural log of total assets.

Firm Size $=$ Ln (total assets $)$

\section{Institutional ownership}

Institutional Ownership is the proportion of share ownership in institutions
(Sujoko\&Ugy, 2007). Ownership of the institution such as insurance companies, pension funds or other companies as measured by percentage is calculated at the end of the year.

$$
I O W N=\frac{\text { Number of Shares Institutional }}{\text { Total Shares Outstanding }} \times 100 \%
$$

\section{Profitability}

Profitability shows the company's ability to operate efficiently, in this study proxy with return on asset (ROA). According Riyadi (2016: 187) ROA is comparing Profit (before tax) with total Asset owned Bank in certain period multiplied $100 \%$.

$$
R O A=\frac{\text { Net profit before } \operatorname{tax}}{\text { Total assets }} \times 100 \%
$$

\section{Leverage}

Leverage is the company's ability to meet all its long-term obligations. Leverage variables, in this case,aredistortion withDAR. Debt to Asset Ratio (DAR) is the ratio of total debt to total assets.

$$
D A R=\frac{\text { Total Debt }}{\text { Total assets }} \times 100 \%
$$

\section{Data Collection Method}

This research uses data collection method in the form of literature study, reviewing various literature and documentation journals with recording.

\section{Data analysis technique}

In this study using path analysis techniques, this technique is an extension of multiple linear regression analysis that detects causality between variables hypothesized with previous theory support (Ghozali, 2013). From the description, the research model as follows: 
Model 1:

$$
\begin{gathered}
C S R D=\beta 1 \text { FirmSize }+\beta 2 \mathrm{IO}+\beta_{3 \mathrm{ROA}} \\
+\beta_{4 \mathrm{DAR}}+\mathrm{e} 1
\end{gathered}
$$

Model 2:

$$
\begin{gathered}
\text { Tobins } Q=\beta 5 \text { FirmSize }+\beta_{6} \mathrm{IO}+\beta_{7 \mathrm{ROA}} \\
+\beta_{8 \mathrm{DAR}}+\beta_{9 \mathrm{CSRD}}+\mathrm{e} 2
\end{gathered}
$$

Explanation: Tobins'Q = company value; Firm Size = company size; $\mathrm{IO}=$ institutional ownership; $\mathrm{ROA}=$ profitability; $\mathrm{DAR}=$ leverage; $C S R D=C S R D$ disclosure rate; $\beta 1$, $\beta 2, \beta 3, \beta 4, \beta 5, \beta 6, \beta 7, \beta 8, \beta 9=$ direct effect coefficient value; $\mathrm{e} 1$ and $\mathrm{e} 2=$ standard error.

\section{Classical Assumption Testing}

In testing, the hypothesis should avoid the deviation of classical assumptions such as normal distribution data, no multicollinearity, heteroscedasticity, and autocorrelation (Ghozali, 2013).

Normality Test

This test is done by testing the certainty of normally distributed data, or close to normal. There are two ways in the first normality test using graph analysis and the second by using statistical analysis. In this study using statistical tests.Kolmogorov Smirnov by detecting a variable significance value, if significant $\geq$ alpha 0.05 indicates normal data distribution.

Multicollinearity Test

This test is done by looking at whether there is a relationship between independent or independent variables that use the value of VIF \& tolerance. There is multicollinearity if VIF $\geq 10$ and tolerance value $\leq 0,10$.

Autocorrelation Test

Test autocorrelation to know the use of error of previous period t- 1 with an error of current period in regression. The cause of the autocorrelation is the length of the observation time sequence interrelated with each other, can be done from the Durbin-Watson test, du $<$ DW $<4$-du (Ghozali, 2013).

Heteroscedasticity Test

Heteroscedasticity test to see residual variance inequality one observation to other observations. There should be no heteroscedasticityin detecting heteroscedasticity using Gletjeror park test, with significance criteria greater than 0.05 or 5\% (Ghozali, 2013).

\section{Hypothesis Testing}

Coefficient of Determination $\left(R^{2}\right)$

$\mathrm{R}^{2}$ test serves to find out how big the power of the model in explaining the variation of the dependent variable (Ghozali, 2013). The weakness in using $\mathrm{R}^{2}$ is the bias on the number of independent variables included in the model. So the best value is to use adjusted $\mathrm{R}^{2}$.

F Test

$\mathrm{F}$ test is to test the significance of firm size, IO, ROA and DAR influence on Tobins'Q simultaneously. According to Gujarati (1995) If $F$ count < F table, meaning independent variables together do not affect the dependent variable. Conversely If $\mathrm{F}$ count $>\mathrm{F}$ table, independent variables simultaneously affect the dependent variable,the hypothesis will be accepted if the probability is less than 0.05 .

t-statistics Test (Partial)

In relation to the hypothesis of this study, then to test the significance of the influence of independent variables on the dependent variable. $\mathrm{H}_{0}$ is accepted if $-\mathrm{t}_{\text {table }}<\mathrm{t}_{\text {count }} \leq \mathrm{t}_{\text {table }}$. $\mathrm{H}_{0}$ is rejected if $\mathrm{t}_{\text {count }}>\mathrm{t}_{\text {table }}$ The last draw is conclusions. 


\section{Mediation Test}

Analysis of the variation of mediation (intervening) is how much direct influence of the independent variable to the dependent variable and indirect variable when through intervening.

\section{Sobel Test}

Sobel test is done to test the hypothesis of mediation that is tested bigger indirect effect of variable $\mathrm{X}$ to $\mathrm{Y}$ through variable $\mathrm{M}$. The influence of the mediation variable can be detected directly by looking at the model in Figure 2 below:

\section{Figure 2}

The Indirect Relationship X Affects through $\mathrm{M}$

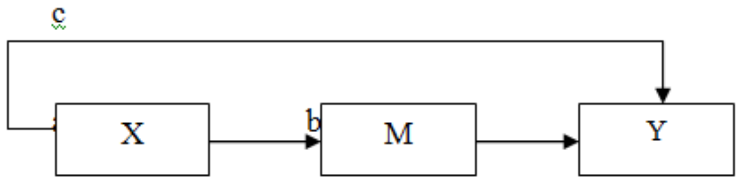

The coefficient of the indirect effect of variable $\mathrm{X}$ on variable $\mathrm{Y}$ through variable $\mathrm{M}$ is calculated by multiplying the path $\mathrm{X} \rightarrow \mathrm{M}$ (a) by the path $\mathrm{M} \rightarrow \mathrm{Y}$ (b) or ab. Thus the coefficient $a b=(c-c)$ where $c$ is the influence of $\mathrm{X}$ against $\mathrm{Y}$ without control $\mathrm{M}$ while $c^{\prime}$ is the coefficient of influence $\mathrm{X}$ against $Y$ after controlling $M$ (Ghozali, 2013). One approach to test the significance of mediation by calculating the standard error of the indirect effect coefficient (Sp2p3).

$$
S_{p 2 p 3}=\sqrt{p 3^{2} S p 2^{2}+p 2^{2} S p 3^{2}+p 3^{2} S p 2^{2}+S p 2^{2} S p 3^{2}}
$$

From $S_{p 2 p 3}$ result can be calculated the tstatistic value of mediation influence which formulated as follows:

$$
\mathrm{t}=\frac{\mathrm{P}_{2} \mathrm{P}_{3}}{\mathrm{Sp}_{2} \mathrm{P}_{3}}
$$

Coefficient has significant influence if $t$ count> t-table is more than 1,96 it can be concluded happened influence of mediation (Ghozali, 2013).

\section{DISCUSSION Descriptive Statistics}

From the statistical data inputted through the financial statements of banking companies listed on the BEI 2012-2016 then it can be seen the descriptive statistic calculation can be seen in Table 1 .

Table 1

Calculation of Minimum Value, Maximum, Mean, Standard Deviation Descriptive Statistics

\begin{tabular}{|l|c|r|r|r|r|}
\hline & $N$ & Minimum & \multicolumn{1}{c|}{ Maximum } & \multicolumn{1}{c|}{ Mean } & \multicolumn{1}{c|}{ Std. Deviation } \\
\hline FS & 145 & 28.56348 & 34.57675 & 31.4737701 & 1.56472772 \\
IO & 145 & 11.03 & 100.00 & 71.4145 & 20.50610 \\
ROA & 145 & -11.15 & 5.15 & 1.5646 & 2.17301 \\
DAR & 145 & .035081 & .929424 & .83594532 & .158826859 \\
CSRD & 145 & 19.04762 & 52.38095 & 32.2058026 & 8.36354869 \\
TOBINSQ & 145 & .127163 & 1.504849 & 1.01743212 & .209147920 \\
Valid N & 145 & & & & \\
(listwise) & & & & & \\
\hline
\end{tabular}




\section{First Equation}

The First Model of Determinant Coefficient Test $\left(R^{2}\right)$

The value of the coefficient of determination can be seen in table 2 .

\section{Table 2}

\section{Coefficient of First Model Determination}

\begin{tabular}{|c|c|r|r|c|}
\hline $\begin{array}{l}\text { Mod } \\
\mathrm{el}\end{array}$ & $\mathrm{R}$ & $\begin{array}{c}\mathrm{R} \\
\text { Square }\end{array}$ & $\begin{array}{c}\text { Adjusted } \\
\text { R Square }\end{array}$ & $\begin{array}{c}\text { Std. The error } \\
\text { of the } \\
\text { Estimate }\end{array}$ \\
\hline 1 & $.710^{\mathrm{a}}$ & .505 & .490 & 6.12742 \\
\hline
\end{tabular}

b. Dependent Variable:

Lag_CSRD1
Adjusted R Square value of 0.490 means 49.00\% CSRD variable can be explained by four independent variables that is FS, IO, ROA, DAR the rest of $51.00 \%$ influenced by other factors from the regression model.

The First Model of F-test (Influence Test simultaneously)

The effect of independent variables (FS, IO, ROA, and DER) on CSR together based on SPSS output results can be seen in table 3 .

Table 3

Calculation of First Model Simultaneous Regression ANOVA $^{\mathrm{b}}$

\begin{tabular}{|ll|r|r|r|r|r|}
\hline Model & & $\begin{array}{c}\text { Sum of } \\
\text { Squares }\end{array}$ & df & Mean Square & \multicolumn{1}{c|}{$\mathrm{F}$} & Sig. \\
\hline 1 & Regression & 5318.652 & 4 & 1329.663 & 35.415 & $.000^{\mathrm{a}}$ \\
& Residual & 5218.787 & 139 & 37.545 & & \\
& Total & 10537.439 & 143 & & & \\
\end{tabular}

a. Predictors: (Constant), Lag_DAR1, Lag_FS1, Lag_IO1, Lag_ROA1

b. Dependent Variable: Lag_CSRD1

The result of $F$ test is 35,415 significance 0,000 so $F$ count $(35,415)>F$ table $(1,96)$ can be concluded that the proposed model has been decent (goodness of fit).
The First Model of Test-t (Partial effect test)

The result of t-testshows that partially influence (FS, IO, ROA, and DAR) on CSRD can be seen in Table 4 .

\section{Table 4}

Partial Regression Calculation of First Model

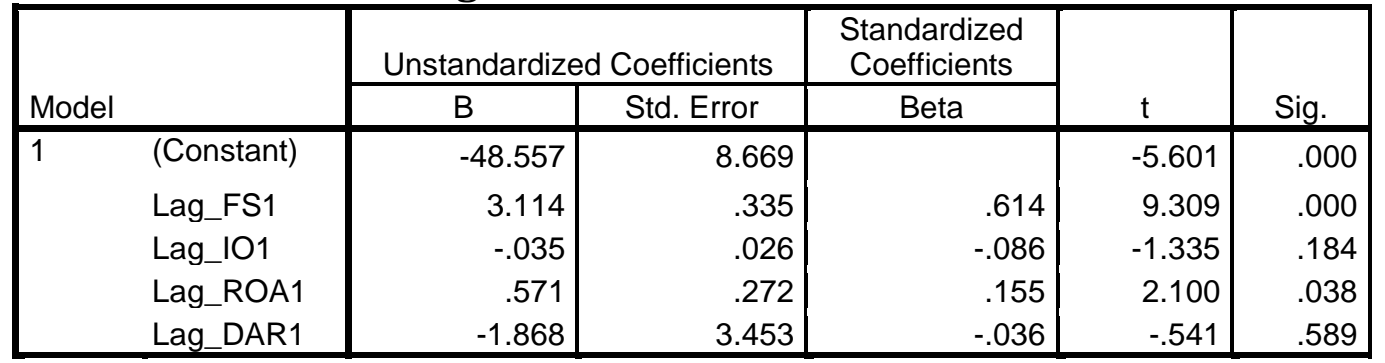

a. Dependent Variable: Lag_CSRD1

The linear regression equation which can be compiled on test result according to table 4.4 above is as follows:

$$
\begin{array}{r}
C S R D=-48,557+3,114 \mathrm{FS}-0,035 \mathrm{IO} \\
+0,571 \mathrm{ROA}-1,868 \mathrm{DAR}
\end{array}
$$

\section{Second Equation}

Second Model of Determinant Coefficient Test $\left(R^{2}\right)$

The value of the coefficient of determination can be seen in table 5 . 
Table 5

Coefficient of Determination of the Second Model

\begin{tabular}{|l|c|r|r|r|}
\hline Model & $\mathrm{R}$ & $\begin{array}{c}\mathrm{R} \\
\text { Square }\end{array}$ & $\begin{array}{c}\text { Adjusted R } \\
\text { Square }\end{array}$ & $\begin{array}{c}\text { Std. The } \\
\text { error of the } \\
\text { Estimate }\end{array}$ \\
\hline 1 & $.804^{\mathrm{a}}$ & .646 & .633 & .12531 \\
\hline
\end{tabular}

b. Dependent Variable:

Lag_TOBINSQ2

The adjusted $\mathrm{R}$ Square value of 0.633 means that $63.30 \%$ of the Tobins' $Q$ variable can be explained by the DAR, ROA, IO, FS, and CSRD variables, while the remaining $36.70 \%$ is explained on the outside regression model.

The Second Model of F-test (Influence Test simultaneously)

Influence of the independent variable (FS, IO, ROA, DAR, CSRD) on TOBINSQ based on the output of SPSS table 6 .

\section{Table 6}

Second Simultaneous Regression Calculation ANOVA $^{b}$

\begin{tabular}{|ll|r|r|r|r|r|}
\hline Model & & Sum of Squares & \multicolumn{1}{c|}{$\mathrm{df}$} & Mean Square & F & Sig. \\
\hline 1 & Regression & 3.955 & 5 & .791 & 50.375 & $.000^{\mathrm{a}}$ \\
& Residual & 2.167 & 138 & .016 & & \\
& Total & 6.122 & 143 & & & \\
\hline
\end{tabular}

a. Predictors: (Constant), Lag_CSRD2, Lag_DAR2, Lag_IO2, Lag_FS2, Lag_ROA2

b. Dependent Variable: Lag_TOBINSQ2

The result of $F$ test is 50,375 with significance 0.000 so $F$ count $(50,375)>F$ table $(1,96)$ with significantly less than 0,05 that is 0.000 so it can be concluded that the proposed model has the goodness of fit.
The Second Model of t-test (Partial influence test

The result of t-test shows that partially influence the independent variable (FS, IO, ROA, DAR, and CSRD) to TOBINSQ can be seen on the table 7 .

Table 7

Second Partial Regression Calculation

\begin{tabular}{|ll|r|r|r|r|r|}
\hline \multirow{2}{*}{ Model } & \multicolumn{2}{|c|}{$\begin{array}{c}\text { Unstandardized } \\
\text { Coefficients }\end{array}$} & $\begin{array}{c}\text { Standardized } \\
\text { Coefficients }\end{array}$ & \multicolumn{1}{c|}{} \\
\cline { 2 - 5 } & \multicolumn{1}{|c|}{$\mathrm{B}$} & \multicolumn{1}{c|}{ Std. Error } & \multicolumn{1}{c|}{ Beta } & \multicolumn{1}{c|}{ Sig. } \\
\hline 1 & (Constant) & -.064 & .315 & & -.204 & .838 \\
& Lag_FS2 & .005 & .009 & .037 & .587 & .558 \\
& Lag_IO2 & .000 & .001 & .028 & .523 & .602 \\
& Lag_ROA2 & .010 & .006 & .100 & 1.586 & .115 \\
& Lag_DAR2 & .875 & .074 & .683 & 11.885 & .000 \\
& Lag_CSRD2 & .005 & .002 & .189 & 2.932 & .004 \\
\hline
\end{tabular}

a. Dependent Variable: Lag_TOBINSQ2

The linear regression equation which can be compiled on test result according to table 7 above is: Tobins $Q=-0,064+0,005 \mathrm{FS}+$ $0,000 \mathrm{IO}+0,010 \mathrm{ROA}+0,875 \mathrm{DAR}+$ 0,005 CSRD

\section{Sobel Test}

CSRD in this study is used as a mediation variable, so it can be known how strong the CSRD variables mediate between independent factors to dependent factors. 
Table 8

Sobel Test Calculation

\begin{tabular}{|l|c|c|c|}
\hline \multicolumn{1}{|c|}{ Variables } & $p 2 p 3$ & \multicolumn{1}{c|}{ Sp2p3 } & \multicolumn{1}{c|}{ tcount } \\
\hline Firm Size & 0,01557 & 0,00648 & 2,40129 \\
\hline IO & 0,00018 & 0,00016 & 1,11794 \\
\hline ROA & 0,00286 & 0,00186 & 1,53715 \\
\hline DAR & 0,00934 & 0,01897 & 0,49245 \\
\hline
\end{tabular}

From table 8can be seen that if $\mathrm{t}->\mathrm{t}$-table significance of $0.05 t$ count $>t$ table (1.96) means CSRD can be an intermediate variable. The results of this study indicate that only firm size variables can be mediated by CSRD because $t$ count $>t$ table (2.40129> 1.96) than for variable IO, ROA, and DAR cannot be mediated CSRD.

\section{DISCUSSION}

\section{The Influence of Firm Size on CSRD}

In the first equation model, the regression coefficient of firm size variables of $(9,309)$ with a significance of 0.000 or below $5 \%$ indicates that firm size ratio has a significant positive effect on CSRD ratios of banking companies listed in the period 2012-2016 so that hypothesis 1 is accepted. On the average data size of banking companies listed on the IDX period, 20122016 can be seen the greater the size of the company the number of CSR disclosure items higher. In this case, the size of the company is reflected in the agency theory that the larger the size of corporate agency costs the greater, which cannot be separated from the pressure with many operating activities and the greater impact on society. This leads to large companies required to pay attention to and safeguard information about the company.

\section{Influence of institutional ownership on CSRD}

The results of this study on the effect of institutional ownership of CSRD with a significance value of 0.184 or above 0.05 so that hypothesis 2 is rejected. The result shows that the indilet is $(-1,335)$ which means negative IO and not significant to CSRD ratio. This indicates that institutional ownership has no effect on CSRD. From the average data on institutional ownership of banking companies from 2012-2016 there is an increase in the percentage of institutional ownership but in this case, does not significantly affect CSR disclosure. This study reflects that institutional ownership has not considered social responsibility as one of the criteria for investing so that institutional investors tend not to press companies to disclose CSR in detail in the company's annual report.

This study found a negative relationship between institutional share ownership and CSR disclosure. This means that the higher level of stock ownership by the institution will reduce the level of CSR disclosure made by the company. This may be due to the fact that institutional investors only aim to maximize personal profit alone regardless of corporate responsibility to other stakeholders.

\section{Effect of Profitability on CSRD}

The results of this study on the effect of profitability to CSRD with a significance value of 0.038 or below 0.05 so that hypothesis 3 accepted. The results indicate that indigo $t$ is (2.100) which means the ROA ratio has a significant positive relation to ratio. This research is in line with agency theory and the theory of legitimacy. In theory, the agency states that the greater the level of profitability will be the wider the company discloses social information. On the theory of legitimacy expressed through high ROA ratios firms will have the opportunity in shaping social contracts with society through disclosure of social information like the existence of the company in the long run. 


\section{Effect of Leverage on CSRD}

The results of this study on the effect of leverage on CSRD with a significance value of 0.589 or above 0.05 so that hypothesis 4 is rejected. The result shows that the indigo $t$ is $(-0.541)$ which means negative leverage and not significant to CSRD ratio. This means that Leverage does not affect CSR disclosure. The level of corporate debt is an internal activity of each company, whether the fund is used for corporate expansion, operational financing or other, in this study the company keeps its CSR activities, so even though the company has a high leverage value does not affect them in implementing CSR programs, aims to attract public confidence in the company.

\section{The Influence of Firm Size on FirmValue}

The result of this research about the influence of firm size to company value (Tobins'Q) with significance value 0.558 or above 0.05 so hypothesis 5 is rejected. The result shows that the indile $t$ is $(0,587)$ which means Firm Size is positive and not significant to firm value (Tobins'Q). This means that firm size has no effect on firm value. This research is not in accordance with the signaling theory that the bigger companies show the company is progressing, the size of the big company shows stable condition and higher investor return rate, it can be positively responded by the investor which make the stock price increase so the company value increase.

The size of the company that is not significant to the value of the company in this study is due to the average data size of banking companies listed on the Stock Exchange by using the company's assets from 2012-2016 there is a successive increase but the company's value proportioned with the ratio of Tobins' $Q$ does not increase even tends to decline in
2012-2015. From these findings means that the greater the total assets owned by the company may not be able to convince investors that the management of the company can increase the value of the company because large companies may not dare to make new investments associated with expansion before the obligations (debt) has been paid.

\section{The Effect of Institutional Ownership on Firm Value}

The results of this study on the influence of institutional ownership of firm value (Tobins' $Q$ ) with a significance value of 0.602 or above 0.05 so that hypothesis 6 is rejected. The results indicate that indigo $t$ is (0.523) which means positive and insignificant institutional ownership of firm value (Tobins'Q). This means that institutional ownership does not affect the firm's value. Large institutional ownership with an average of $71.41 \%$ is the majority owner. According to Pound (in Diyah and Erman, 2009), majority institutional investors have a tendency to compromise or side with management and ignore the interests of minority shareholders. The notion that management often takes nonoptimal actions or policies and tends to lead to personal interests results in an alliance strategy between institutional investors and management responding negatively to the market.

Institutional investors are temporary owners (transfer owners) so that only focused on current earnings (current earnings). Changes in earnings can now influence institutional investors' decisions. If this change is felt unprofitable by investors, then investors can withdraw their shares. Since institutional investors have large shares if they withdraw their shares will affect the value of the stock as a whole. This means that institutional 
ownership has not been able to become a mechanism for improving company value.

\section{The Effect of Profitability on Firm Value}

The result of this research is about the effect of profitability proxied by ROA to company value (Tobins'Q) with significance value 0,115 or above 0,05 so hypothesis 7 is rejected. The result shows that the indile $t$ is (1.586) which means profitability (ROA) is positive and not significant to firm value (Tobins'Q). This means that profitability has no effect on firm value. The smaller the profitability of a company will be reduced also the value of the company caused by the lack of interest companies to buy shares of the it's company.Hal is not in line with existing data occurred at Bank Victoria Tbk, the smaller ROA from 2012-2016 with the value of the company decreasing in the year 2012-2016 but the number of stocks circulating the higher, investors assess the use of less effective assets to get the optimal profit so that investors pay less attention to profitability indicators in making investments.

\section{Effect of Leverage on Firm Value}

The results of this study on the effect of leverage that is proclaimed with DAR on firm value (Tobins'Q) with a significance value of 0.00 or below 0.05 . The results indicate that indigo $t$ is (11.885) which means leverage (DAR) is positive and significant against firm value (Tobins'Q). so hypothesis8 is rejected. Leverage has a positive and significant effect on the value of the company means that the higher the leverage the value of the company increases and the lower the leverage then the value of the company decreases. From the average data of banking companies listed on the IDX period 2012-2016, there is a decrease in leverage ratio or lower leverage value and decreasing company value.
Investors see that firms with high leverage exhibit good prospects in the future with the assumption that future cash flows in the future will be maintained. One way to control these costs is by issuing debt since the addition of debt requires a commitment to interest and principal repayments that can reduce the company's cash, thereby reducing the manager's ability to wastage and making resource use more productive. In addition, with the debt also shows the optimism of management in making the investment so it is expected that the future prospects are getting better, high investment is a signal of corporate revenue growth in the future. This can attract investors to buy shares of the company, thus increasing demand for stocks. High stock demand can increase stock prices. High stock prices reflect the value of the company is getting higher.

\section{The influence of CSRD on Firm Value}

The result of this research is about the influence of CSRD which is proxied by DAR to Firm value (Tobins'Q) with significance value 0.004 or below 0.05 . The results indicate that indigo $t$ is (2.932) which means CSRD is positive and significant against firm value (Tobins'Q). so hypothesis 9 is accepted. CSR means factors that can affect the value of the company so that companies need to pay attention to the activity and quality of CSR disclosure.

The Effect of Firm Size on Company Value mediated by CSRD

The result of hypothesis test 10 shows that CSRD variable able to mediate between firm size and company value so that hypothesis 10 is accepted. The size of the company can affect the extent of CSR disclosure this can be a signal for investors is to buy companies that have prospects in the future. 
The Effect of Institutional Ownership on Firm Value mediated by CSRD

The result of hypothesis test 11 states that CSRD cannot be mediation between institutional ownership of Company value (Tobins'Q). From Table 4.12 shows the coefficient of direct influence is very small then test significance sobel test shows t-count equal to $1.11794 \mathrm{t}$-count $<\mathrm{t}$ table is 1,960 which means CSRD does not significantly mediate between institutional ownership of Company Value.

\section{Effect of Profitability on Company Value mediated by CSRD}

The result of hypothesis test 12 states CSRD cannot be mediation between Profitability (ROA) against Company value (Tobins'Q). So hypothesis 12 is rejected. From Table 4.12 shows the coefficient of direct influence is smaller than the indirect influence through CSRD and test significance sobelt test shows $t$-count of 1.53715 t-count $<\mathrm{t}$-table is 1.960 which means CSRD does not significantly mediate between Profitability to Company Value.

\section{Effect of Leverage on Company Value mediated by CSRD}

The result of hypothesis test 13 states that CSRD cannot be mediation between Leverage (DAR) against Company value (Tobins'Q). So hypothesis 13 is rejected. From table 4.12 shows the coefficient of direct influence is smaller than the indirect influence through CSRD and test significance sobelt test shows $t$ count of $1.49245 \mathrm{t}$-count $<\mathrm{t}$-table is 1.960 which means CSRD is not significantly able to mediate between leverage to Company Value.

\section{CONCLUSION AND SUGGESTION Conclusion}

Based on the results of data analysis and discussion that have been presented, can be obtained some conclusions as follows:

1. The result of hypothesis test 1 shows that the partial variable of Company Size has positive and significant effect on CSRD variable meaning hypothesis 1 is accepted.

2. The result of hypothesis test 2 shows that partially variable of Institutional Ownership has the negative and insignificant effect to CSRD variable meaning hypothesis 2 is rejected.

3. The result of hypothesis 3 test shows that partially Profitability (ROA) variables have positive and significant effect to CSRD ratio means hypothesis 3 accepted.

4. The result of hypothesis test 4 shows that partially Leverage variable has a negative and insignificant effect to CSRD meaning hypothesis 4 is rejected.

5. The result of hypothesis test 5 shows that the partial variable of Company Size has a positive and insignificant effect to Firm Value means hypothesis 5 is rejected.

6. The result of hypothesis test 6 shows that a partially variable of Institutional Ownership has the positive and insignificant effect to Firm Value means hypothesis 6 is rejected.

7. The result of hypothesis test 7 shows that partially Profitability variable has a positive and insignificant effect to Firm Value means hypothesis 7 is rejected.

8. The result of hypothesis test 8 shows that partially Leverage variable has a positive and significant effect to firm value mean that hypothesis 8 is rejected.

9. The result of hypothesis 9 test shows that partially CSRD has positive and 
significant effect to Firm Value means hypothesis 9 accepted.

10. The results of hypothesis 10 test show that CSRD able to mediate the influence of firm size to firm value means hypothesis 10 accepted.

11. The result of hypothesis test 11 shows that CSRD does not mediate the effect of Institutional Ownership on Firm Value means hypothesis 11 is rejected.

12. The result of hypothesis 12 test shows that CSRD does not mediate the influence of Profitability to Firm Value meaning hypothesis 12 is rejected.

13. The result of hypothesis 13 test shows that CSRD does not mediate the effect of Leverage on Firm Value means hypothesis 13 is rejected.

14. In this research which has direct influence that is leverage variables, furthermore, have the significant indirect effect that is variable of Firm size and profitability through CSRD variable.

\section{Suggestion}

In this research the suggested policy implications are as follows:

1. Management should increase the company's assets and earnings so as to increase CSR disclosure furthermore the company can increase the information of CSR disclosure in terms of activity and quality of CSR disclosure in the annual report that can be used as a competitive advantage company, so that investors will respond positively which ultimately can increase the value company.

2. Leverage directly affects the company value. Therefore advice for management should be in the use of debt runs effectively so as to generate optimal profit which can further increase the firm value.

\section{REFERENCES}

Eipstein, Marc J. and Martin Freedman. 1994. Sosial Disclosure and the Individual Investor. Accounting, Auditing and Accountability Journal.Vol. 7, No. 4, p. 94-108

Anggraini, Retno. (2006). Pengungkapan Informasi Sosial dan Faktor factor yang Mempengaruhi Pengungkapan Informasi Sosial dalam Laporan Keuangan Tahunan. Simposium Nasional Akuntansi IX, 2006.

Ghozali, Imam. (2013). Aplikasi Analisis Multivariate dengan Program. Edisi Ketujuh. Semarang; Badan Penerbit Universitas Diponegoro.

Jensen, Michael C dan William H. Meckling. 1976.Theory of the Firm: Managerial Behavior, Agency Costs and Ownership Structure. The Journal OfFinancialEconomics, 3 (4): 305360

Masdupi .(2005). Analisis Dampak Struktur Kepemilikan Pada Kebijakan Hutang dalam Mengontrol Konflik Keagenan. JurnalEkonomi dan Bisnis.

O'Donovan, 2002. Environmental Disclosure in the Annual Report Extending the Applicability and Predictive Power of LegitimancyTheory,Accounting, Auditing and Accountability Journal , Vol.15,No.3,pp 344-371

Riyadi, Selamet (2016). Banking Assets and Liability Managemen. Edisi Keempat. Lembaga Penerbit Fakultas Ekonomi dan Bisnis: Universitas Indonesia. 
Sembiring, Eddy Rismanda. "Karakteristik Perusahaan dan Pengungkapan Tanggungjawab Sosial Pada Perusahaan yang Tercatat di Bursa Efek Jakarta". Simposium Nasional Akuntansi 7, (15-16 Desember 2005).

Sujoko, dan Soebiantoro, Ugy. 2007. PengaruhStrukturKepemilikanSaham, Leverage, Faktor Intern danFaktorEksternterhadapNilai Perusahaan (StudiEmpirikpada Perusahaan Manufakturdan Non Manufaktur di Bursa Efek Jakarta). JurnalManajemendanKewirausahaan, 9(1), hal: 41-48.

Tjia, Olivia and Lulu Setiawati. (2012), "Effect of CSRD Disclosure to Value of the Firm: Study for Banking Industry in Indonesia”, World Journal of Social Sciences, 2 (6) September 2012 Issue: 169 - 178

Wahyudi, U. dan P.H. Pawestri. 2005. Implikasi Struktur Kepemilikan Terhadap Nilai Perusahaan: Dengan Keputusan Keuangan Sebagai Variabel Intervening. Simposium Nasional AkuntansiIX. Padang 23-26 Agustus.

Wahyudi, Sugeng.(2013). The Effectivity of Internal and External Corporate Governance Mechanisms Toward Corporate Performance. Research Journal of Finance and Accounting, Vol.4 No.4, 132 - 140, ISSN 2222-1697.

Yao, S., Wang, J., and Song, L. 2011.Determinants of Social Responsibility Disclosure by ChinesseFirms.Discussion Paper 72. Nottingham: The University of Nottingham. 